Михайловська Олена Василівна кандидат економічних наук, доцент, доцент кафедри публічного управління та менеджменту організацій Національний університет «Чернігівська політехніка», вул. Шевченка, 95, м. Чернігів, 14035, тел.: (050) 355-02-85, e-mail: m-olena@ukr.net, https:// orcid.org/0000-0002-7682-2292

Воронко Андрій Олегович аспірант кафедри публічного управління та менеджменту організацій Національний університет «Чернігівська політехніка», вул. Шевченка, 95, м. Чернігів, 14035, тел.: (063) 554-17-82, e-mail: voronko.andrey181292@gmail.com

\title{
РЕАЛІЗАЦІЯ ЗМІН В ПУБЛІЧНОМУ УПРАВЛІННІ
}

Анотація. Досліджено розуміння сутності поняття «зміна», що формує нове бачення ефективних перетворень в публічній сфері. Наголошено на необхідності посилення уваги до пошуку ефективних шляхів підвищення ймовірності успіху змін на рівні громадянського суспільства. Схарактеризовано схожість та різницю між приватним та державним секторами у напрямі задоволення соціальних потреб. Підкреслено, що забезпечення успішних змін і стійке підвищення ефективності в громадській сфері - це робота з унікальними перешкодами. Зазначено, що зазвичай при вирішенні проблем в управлінні вдаються до традиційних методів реагування на зміни, але такий підхід вже не є актуальним в публічній сфері. Управління змінами визнано критичною технологією, що використовується у процесі управлінської діяльності задля підвищення ймовірності успіху. Наголошено, що управління змінами має за мету - забезпечити переваги й бажані результати зміни. Представлено узагальнену схему процесу управління змінами та класичні моделі управління змінами. Вказано, що в Україні суспільство прагне перейти до проєктного мислення з постановкою чітких цілей та розробкою плану дій. Представлено взаємозв'язок понять «зміна», «управління змінами», «управління проєктами» та обов'язкові складові механізму управління змінами. Наведено методи оцінки ймовірності успіху змін та розроблено узагальнену схему процесу управління змінами в публічній сфері. Наголошено на необхідності використання технології управління змінами у практичному фокусі. Визначені позитивні зрушення у даному напрямі: погодження Національним агентством України 3 питань державної служби загальної короткострокової програми підвищення кваліфікації «Управління змінами», що, безперечно, можна визнати позитивним аспектом; наявність методичного забезпечення з управління змінами. 
Ключові слова: управління змінами, управління проєктами, публічне управління, публічна сфера, зміна, процес.

Mykhailovska Olena Vasylivna Candidate of Economic Sciences, Associate Professor, Associate Professor at the Department of Public Administration and Organizations' Management in Chernihiv Polytechnic National University, Shevchenko St., 95, Chernihiv, 14035, tel.: (050) 355-02-85, e-mail: molena@ukr.net, https://orcid.org/0000-0002-7682-2292

Voronko Andriy Olehovych Graduate student at the Department of Public Administration and Organizations' Management in Chernihiv Polytechnic National University, Shevchenko St., 95, Chernihiv, 14035, tel.: (063) 554-17-82, e-mail: voronko.andrey181292@gmail.com

\section{IMPLEMENTATION OF CHANGES IN PUBLIC GOVERNANCE}

Abstract. The understanding of the essence of the concept of "change", which forms a new vision of effective transformations in the public sphere, is investigated. Emphasis is placed on the need to pay more attention to finding effective ways to increase the likelihood of success of change at the level of civil society. The similarities and differences between the private and public sectors in the direction of meeting social needs are characterized. It is emphasized that ensuring successful change and sustainable efficiency in the public sphere is a work with unique obstacles. It is noted that usually in solving problems in management resort to traditional methods of responding to change, but this approach is no longer relevant in the public sphere. Change management is recognized as a critical technology used in the management process to increase the likelihood of success. It is emphasized that change management aims to provide the benefits and desired outcomes of change. The generalized scheme of change management process and classical models of change management are presented. It is stated that in Ukraine the society strives to move to project thinking with setting clear goals and developing an action plan. The relationship between the concepts of "change", "change management", "project management" and the mandatory components of the change management mechanism are presented. Methods for assessing the probability of success of change are presented and a generalized scheme of the process of change management in the public sphere is developed. The need to use change management technology in practical focus is emphasized. Positive developments in this direction have been identified: approval by the National Agency of Ukraine for Civil Service Affairs of the general short-term training program "Change Management", which, of course, can be considered a positive aspect; availability of methodological support for change management.

Keywords: change management, project management, public sphere, public management, change, process. 
Постановка проблеми. Як відомо публічне управління має бути спрямоване на реалізацію цінностей громадянського суспільства. В умовах сьогодення зазначене передбачає докорінну зміну формату спілкування держави та громадян в Україні. Водночас прийняті рішення повинні приносити максимальний результат при мінімально можливих втратах, тому вони мають бути обгрунтованими в умовах оперативності. У даному аспекті управління змінами можна вважати однією 3 найбільш прогресивних управлінських технологій, що продовжують швидко розвиватись. Однак, варто підкреслити, що сьогодні інструменти менеджменту змін не знайшли належного розповсюдження в управлінсько-практичній діяльності, не дивлячись на теоретичні напрацювання та, нажаль, залишаються доволі невідомим напрямом у методиці управління. Варто наголосити, що в публічній сфері питання менеджменту змін у більшості випадків досліджуються у фокусі певних адміністративних одиниць. Зазначене спонукає до пошуку ефективних шляхів управління змінами в умовах сьогодення.

Аналіз останніх досліджень і публікацій. Вчені продовжують активно досліджувати шляхи підвищення ефективності менеджменту змін у практичній сфері публічного управління. зокрема, теоретичні аспекти опрацьовували: І. Адізес, М. Білінська, У. Бридж, Пітер Ф. Друкер, К. Левін, Н. Обушна, Т. Пічугіна, Дж. Хубер, Ю. Шаров та інші. Водночас в управлінський теорії належного висвітлення не знайшли питання удосконалення процесу управління змінами у рамках національної публічної сфери.

Мета статті. Визначення актуальних шляхів формування якісної системи управління змінами в публічній сфері.

Виклад основного матеріалу. Загальновідомо, що зміна - це перехід 3 одного якісного стану в інший якісний стан, перетворення на інше. У період трансформаційних змін в Україні варто враховувати не лише час, кошти та інші ресурси, а й сприйняття змін почуттями (нематеріальні зміни), що формують нове бачення ефективних перетворень. 3 даного приводу у наукових джерелах висвітлюються питання управління змінами в державних органах влади та майже на приділяється увага ефективним шляхам підвищення ймовірності успіху змін на рівні громадянського суспільства (інститутів громадянського суспільства).

Сьогодні приватний сектор домігся вражаючих успіхів в продуктивності своєї діяльності, тому актуальним напрямом можна вважати пошук ринкових рішень у напрямі задоволення соціальних потреб. Високоефективні державні установи сьогодні дуже часто ототожнюються 3 добре керованими компаніями, оскільки вони мають спільні цілі, які добре продумані; відповідальність; ефективних лідерів. Водночас існують і глибокі відмінності в їх цілях, культурах і контекстах, що створює абсолютно різні перешкоди у процесі їх діяльності. Зазначимо про те, що найбільша проблема в забезпеченні успішних змін і значного та стійкого підвищення ефективності 
в громадській сфері - це не стільки пошук рішень, які в більшості своїй прості, скільки робота з унікальними перешкодами.

Як правило, при вирішенні проблем в управлінні вдаються до традиційних методів реагування на зміни, які полягають в «ручному управлінні», методи якого грунтуються на особистому досвіді і суб'єктивних припущеннях. Однак, такий підхід вже не є актуальним в публічній сфері.

У даному випадку управління змінами можна вважати критичною технологією, що використовується у процесі управлінської діяльності задля підвищення ймовірності успіху. Сьогодні розповсюджене твердження згідно 3 яким зміни - це проєкт, ініціатива або рішення, що впроваджується в організації для покращення способів виконання робіт, вирішення проблемних питань або використання можливостей [1]. Водночас управління змінами має визначену мету - забезпечити переваги й бажані результати зміни. Узагальнена схема процесу управління змінами представлена на рис. 1.

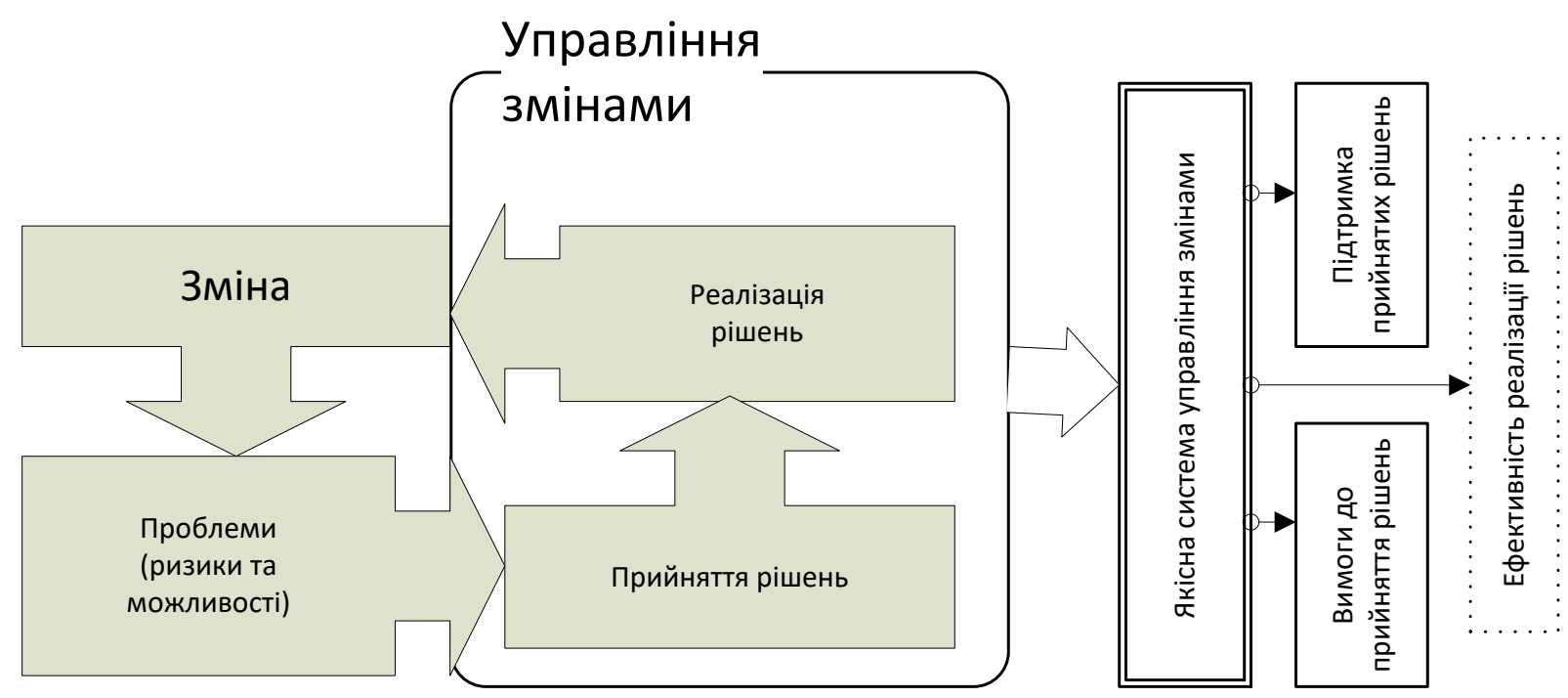

Рис. 1. Формування якісної системи управління змінами в публічній cфpepi

Джерело: розроблено авторами на основі [1]

Тобто, у загальному вигляді управління змінами - це інструмент, який необхідно застосовувати незалежно від фактичних змін, які вживаються. На сьогодні вже сформувались класичні моделі управління змінами (рис. 2). 


\begin{tabular}{|c|c|}
\hline Модель & Характеристика \\
\hline Дж. Коттер & $\begin{array}{c}\text { Включає } 8 \text { кроків: 1) подолання стану задоволеності поточною ситуацією; 2) формування команди для проведення зміни; } \\
\text { 3) визначення бачення бажаного майбутнього і стратегії переходу; 4) інформування про проведені зміни; 5) усунення } \\
\text { перешкод, що заважають проведенню змін; 6) досягнення швидких успіхів; 7) підтримка процесу змін; 8) закріплення } \\
\text { проведених змін }\end{array}$ \\
\hline $\begin{array}{l}\text { Теорія } \\
\text { обмежень, } \\
\text { розроблена Еліяху } \\
\text { Моше Голдраттом }\end{array}$ & $\begin{array}{c}\text { - базується на пошуку і управлінні ключовим обмеженням системи, яке визначає успіх і ефективність усієї системи в } \\
\text { цілому; } \\
\text { - націленість на взаємовигідні рішення дозволяє підвищувати рівень взаємодії й мотивацію персоналу; } \\
\text { - містить логічних інструментів, що дозволяють знайти обмеження, виявити управлінське протиріччя, що стоїть за ним, } \\
\text { підготувати рішення й впроваджувати його з урахуванням інтересів усіх зацікавлених сторін }\end{array}$ \\
\hline Модель ADKAR & $\begin{array}{c}\text { Включає } 5 \text { етапів: Awareness (Усвідомлення) - усвідомлення необхідності змін; Desire (Бажання) - бажання взяти участь і } \\
\text { підтримати зміни; Knowledge (Знання) - що необхідно зробити для зміни; Ability (Уміння) - реалізація змін; } \\
\text { Reinforcement (Закріплення) - закріплення здійснених змін, преміювання }\end{array}$ \\
\hline $\begin{array}{l}\text { Методологія AIM } \\
\text { (Accelerated } \\
\text { Implementation } \\
\text { Methodology) }\end{array}$ & $\begin{array}{c}\text { Містить } 10 \text { основних кроків, покладених в } 3 \text { етапи проведення змін - етап планування, етап застосування і етап } \\
\text { моніторингу досягнутих результатів. }\end{array}$ \\
\hline \begin{tabular}{l} 
Модель \\
управління \\
\hdashline змінами Бекхарда \\
$\quad$ і Харріса
\end{tabular} & $\begin{array}{l}\text { Передбачає, що успішне проведення змін можливо в тому випадку, якщо набір факторів, що підштовхують до змін } \\
\text { (незадоволеність, бажання отримати щось, необхідність в отриманні бажаного) буде сильніше опору цим змінам. }\end{array}$ \\
\hline $\begin{array}{l}\text { Модель переходу : } \\
\text { Вільяма } \\
\text { Бріджеса }\end{array}$ & Включає 3 етапи переходу: 1) закінчення, втрата і відпускання втраченого; 2) нейтральна зона; 3) новий початок. \\
\hline $\begin{array}{l}\text { модель Кублер- } \\
\text { Росса }\end{array}$ & $\begin{array}{l}\text { Включає } 4 \text { етапи реакції на зміни: 1) негативна реакція на будь-які зміни; 2) побоювання від наслідків змін; } \\
\text { 3) адаптація до змін; 4) прийняття змін і активна роботою в нових умовах. }\end{array}$ \\
\hline $\begin{array}{l}\text { Модель Курта } \\
\text { Левіна }\end{array}$ & $\begin{array}{c}\text { Включає } 3 \text { фази проведення зміні: розморожування - проведення змін - заморожування. } \\
\text { На першій фазі робляться спроби знизити опір змінам, на третій - інституалізація проведених змін, вироблення звички, } \\
\text { щоб люди не повернулися до старих методів і способів роботи. }\end{array}$ \\
\hline
\end{tabular}

Pис. 2. Характеристика основних моделей управління змінами Джерело: узагальнено авторами

Деякі науковці вказують на те, що стратегії та тактики управління змінами є синонімами у державному управління та бізнес-секторі. Однак, сьогодні в Україні суспільство прагне перейти до проєктного мислення 3 постановкою чітких цілей та розробкою плану дій. Важливо враховувати $\mathrm{i}$ той факт, що стійкість до змін, як правило, зумовлена страхом перед невідомим. Зазвичай управління проєктами та управління змінами виглядають по-різному для кожної ініціативи. Обсяг управління проєктом залежить від складності та ступеня зміни існуючих процесів, систем, організаційної структури та робочих ролей. Участь в управлінні змінами залежить від атрибутів організації, таких як культура, система цінностей та історія минулих змін. Сьогодні публічним управлінцям поки що важко відокремити самі зміни від управління проєктом та управління змінами. На практиці ці компоненти тісно взаємопов'язані для забезпечення позитивного результату. Однак, в теоретичному плані доцільно їх розмежовувати (рис. 3). Поділ даних компонентів полегшує визначення і допомагає зрозуміти окремі 
елементи більш чітко. Такий поділ також є важливий при усуненні недоліків в конкретному проєкті.

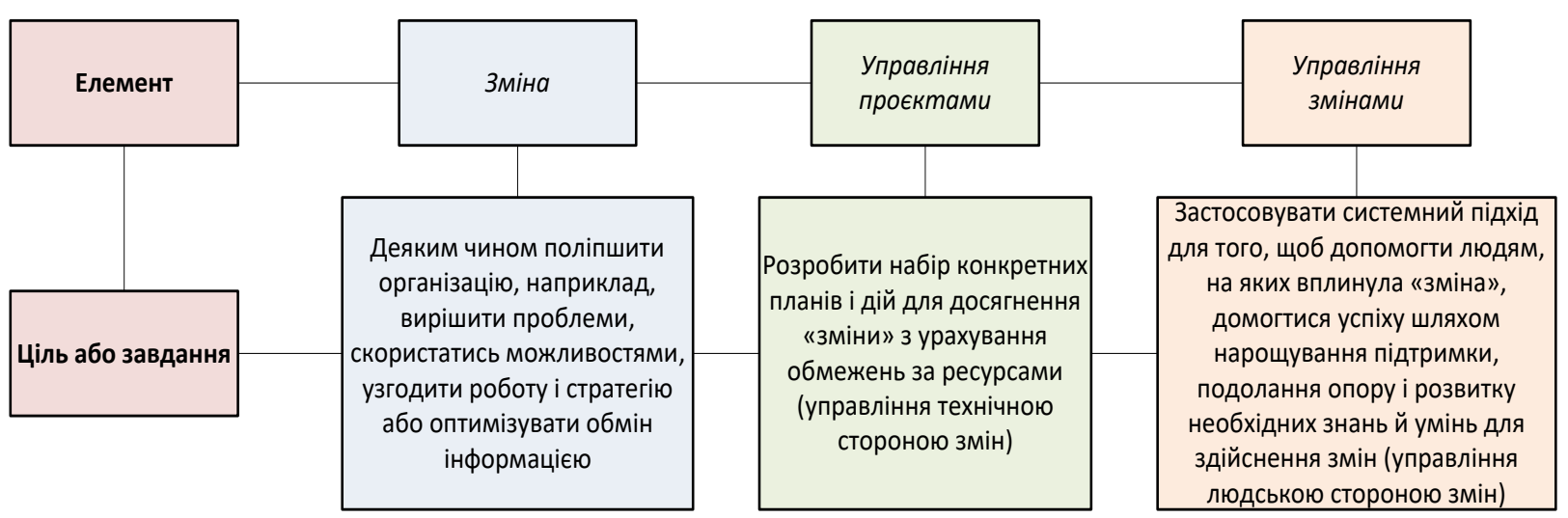

Рис. 3. Взаємозв'язок понять «зміна», «управління змінами», «управління проєктами»

Джерело: розмежовано та побудовано авторами

Враховуючи зазначене у загальному розумінні механізм управління змінами має включати певні складові (рис. 4).

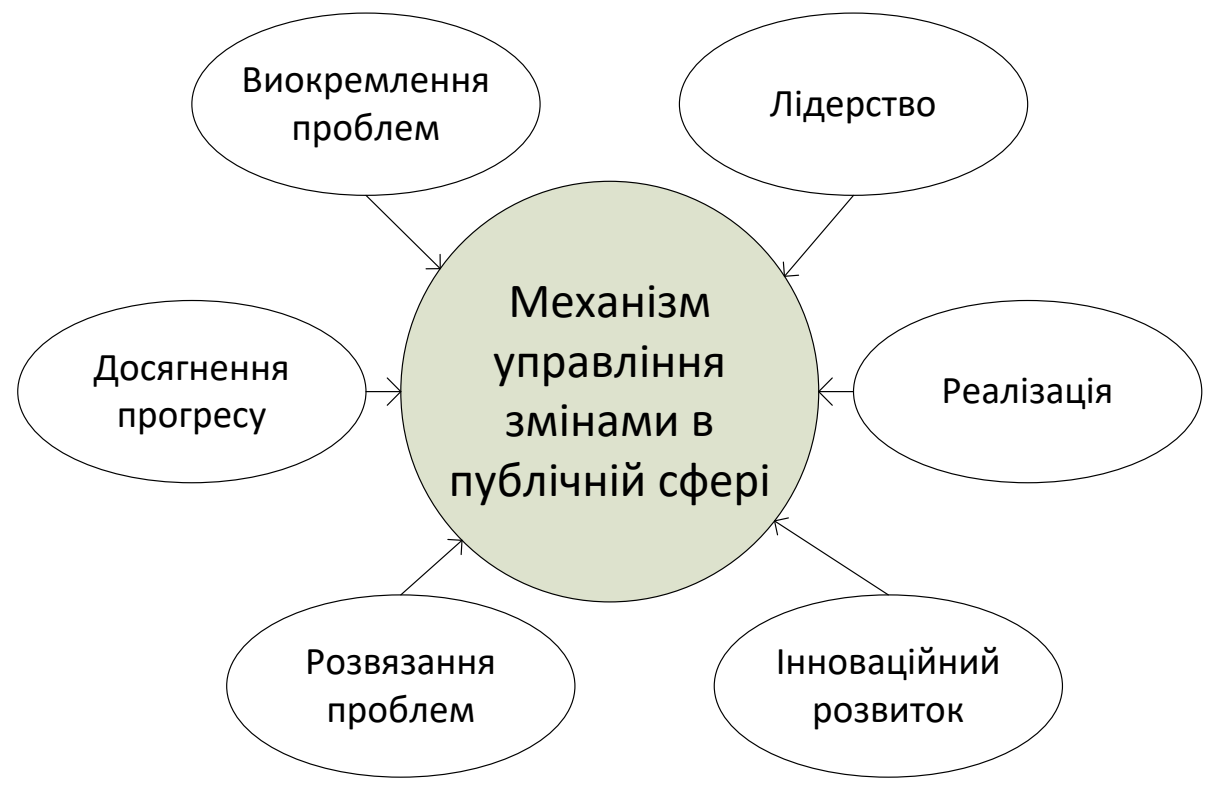

Pис. 4. Обов'язкові складові механізму управління змінами Джерело: запропоновано авторами

Загальновідомо, що для уникнення проблематичних питань у процесі управління змінами необхідно розробити чіткий план. У даному випадку доцільно використовувати вже існуючі розробки, які довели свою ефективність (рис. 5). 


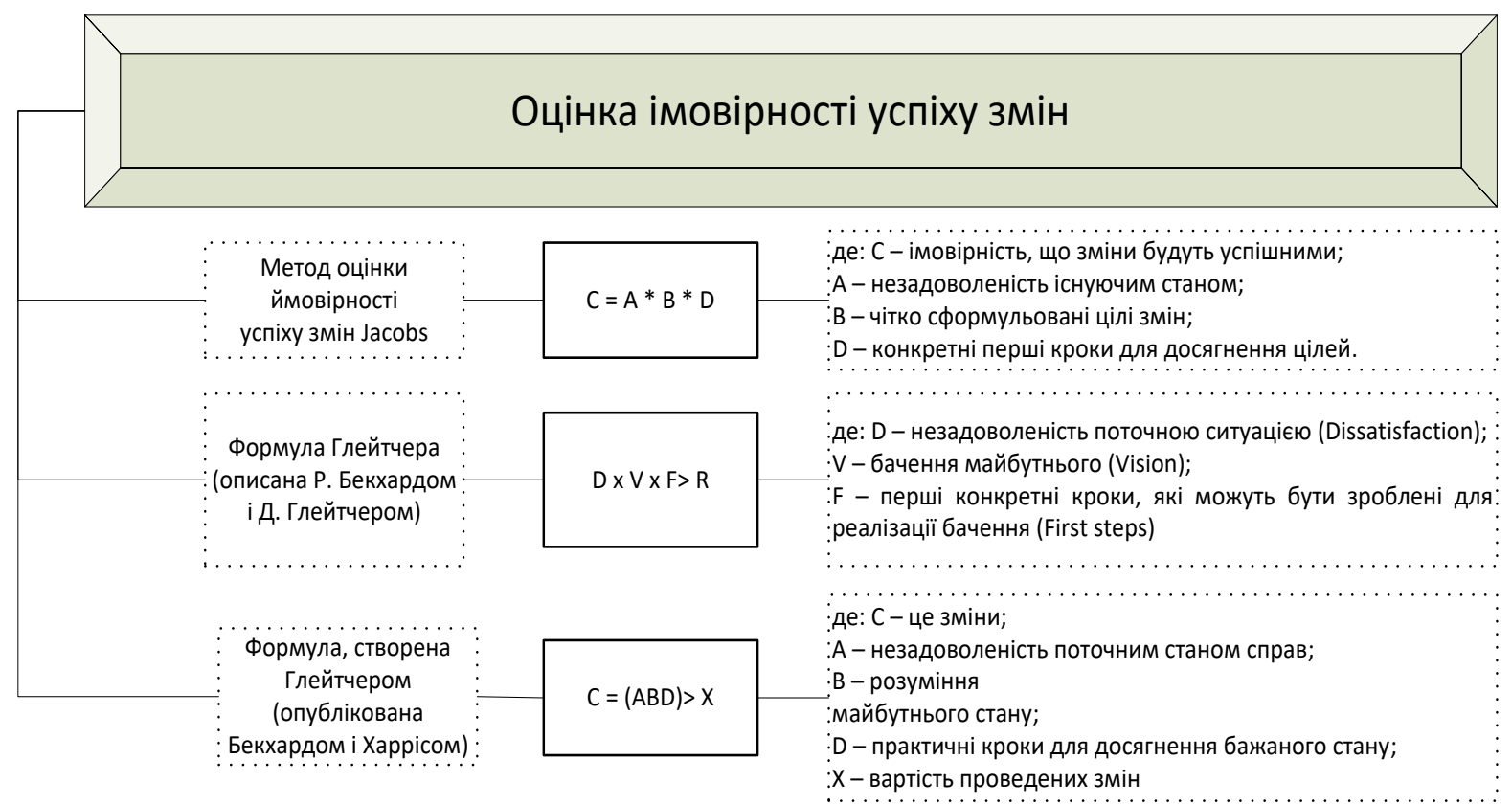

Puc. 5. Методи оцінки ймовірності успіху змін Джерело: узагальнено авторами

Тож, можемо представити узагальнену схему управління змінами в публічній сфері (рис. 6). У даному випадку процес управління змінами має спрямований характер.

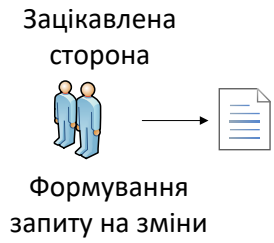

Адміністратор

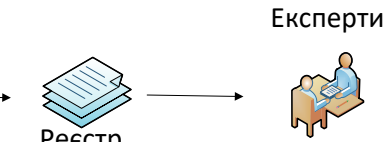

Аналіз відкритих запитів на зміни (зміни термінові чи стандартні); уточнення параметрів змін

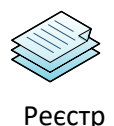
результатів

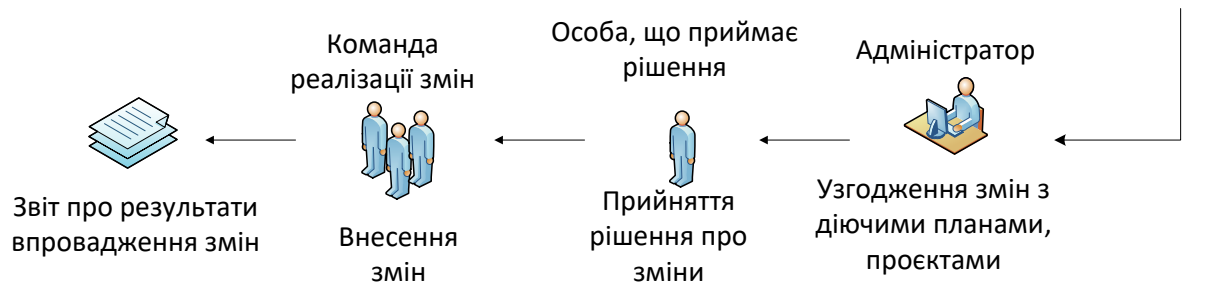

Рис. 6. Процес управління змінами в публічній сфері (узагальнена схема) Джерело: розроблено авторами

Для підвищення ефективності процесу управління змінами у практичному фокусі постійно розробляється певна програмна підтримка. Сьогодні велика кількість компаній опрацьовує професійне програмне забезпечення не лише за кордоном, а й в Україні. Такі програми постійно удосконалюються та адаптуються під потреби замовників. Досліджуючи практичні аспекти щодо дій у напрямі підвищення ефективності процесу впровадження змін також варто зазначити й про позитивні зрушення, а саме: 
1) Національне агентство України з питань державної служби (НАДС) погодило загальну короткострокову програму підвищення кваліфікації державних службовців та посадових осіб місцевого самоврядування «Управління змінами», що, безперечно, можна визнати позитивним аспектом. Однак, виходячи зі змісту представленої програми, на наш погляд, часу для охоплення всього матеріалу замало (всього п'ятнадцять годин), що говорить лише про поверхневе дослідження напрямів використання даної технології. Тобто, бажано було б акцентувати увагу у такій програмі на ключових питаннях, які спрямовані на удосконалення процесу впровадження змін з урахуванням національних особливостей. На офіційному сайті НАДС також представлено перелік онлайн платформ для самоосвіти 3 безкоштовними програмами підвищення кваліфікації, які стосуються проблематики забезпечення ефективності впровадження змін (https://pdp.nacs.gov.ua/news/pidbirka-onlain-platform-dlia-samoosvity).

2) Адміністрація міст України (АМУ) пропонує свою добірку онлайнкурсів та вебінарів за тематикою діяльності органів місцевого самоврядування, що покликані удосконалити процес реалізації змін на різних рівнях публічного управління (https://auc.org.ua/novyna/amu-proponuyedobirku-onlayn-kursiv-ta-vebinariv-za-tematykoyu-diyalnosti-organiv-miscevogo).

3) У 2017 році було представлено посібник з управління змінами для місцевих та регіональних органів влади, що розроблений Міжнародною організацією розвитку Ltd. (IOD PARC) [2]. Посібник містить загальну інформацію про низку інструментів, скерованих на підтримку базового рівня, збирання даних та аналізу проєктів або місцевих ініціатив та включає вступні рекомендації щодо шести інструментів моніторингу та огляду.

Висновки. Отже, управління змінами можна вважати однією з найбільш прогресивних управлінських технологій, що продовжують швидко розвиватись. Однак, сучасні наукові напрацювання у даному аспекті не знаходять свого повного відображення у практичному використання. Позитивні зрушення не носять комплексного характеру, а спостерігаються лише у поодиноких випадках, що не сприяє формуванню якісною системи управління змінами в публічній сфері. Водночас розмежування понять «зміна», «управління змінами», «управління проєктами» у практичній сфері, аналіз складових механізму управління змінами та використання методів оцінки ймовірності успіху змін сприятиме кращому розумінню публічними управлінцями самого процесу та використанню наявних можливостей підвищення якості системи управління змінами.

\section{Лimepamypa:}

1. Савельєв В. Застосування фінансового механізму при ухваленні управлінських рішень. Kreston GCG. 2019. URL: https://kreston-gcg.com/ua/\%D0\%B0pplication-of-financialmodeling-in-making-management-decisions/ [дата звернення 15.06.2021].

2. Управління змінами. Електронний посібник для місцевих та регіональних органів влади. Міжнародна організація розвитку Ltd. (IOD PARC). Грузія, 2017. URL: https://rm.coe.int/management-of-change-ukr-web/16807850ef [дата звернення 10.06.2021]. 
3. Best Practices in Change Management. Thought Leadership. Prosci Portal Article. URL: https://www.prosci.com/resources/articles [дата звернення 05.06.2021].

4. Frank Ostroff Change Management in Government. Harvard Business Publishing. 2006 URL: https://hbr.org/2006/05/change-management-in-government [дата звернення 11.06.2021].

5. Joris van der Voet, Ben Kuipers, Sandra Groeneveld. Held back and pushed forward: leadingchange in a complex public sector environment. Journal of Organizational Change

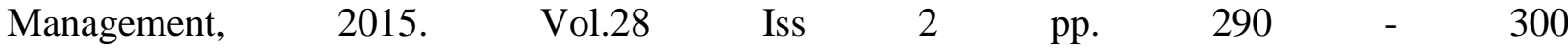
URL:https://www.researchgate.net/publication/276108170_Held_back_and_pushed_forward_Le ading_change_in_a_complex_public_sector_environment [дата звернення 22.06.2021].

\section{References:}

1. Saveliev V. (2019) Zastosuvannia finansovoho mekhanizmu pry ukhvalenni upravlinskykh rishen. [Application of the financial mechanism in making management decisions]. Kreston GCG. URL: https://kreston-gcg.com/ua/\%D0\%B0pplication-of-financialmodeling-in-making-management-decisions/ [accessed Jun 15 2021]. [in Ukrainian].

2. Upravlinnia zminamy (2017) Elektronnyi posibnyk dlia mistsevykh ta rehionalnykh orhaniv vlady [An electronic guide for local and regional authorities]. Mizhnarodna orhanizatsiia rozvytku Ltd [International Development Organization Ltd]. (IOD PARC). Hruziia.URL: https://rm.coe.int/management-of-change-ukr-web/16807850ef [accessed Jun 10 2021]. [in Ukrainian].

3. Best Practices in Change Management. Thought Leadership. Prosci Portal Article. URL: https://www.prosci.com/resources/articles [accessed Jun 05 2021]. [in English].

4. Frank Ostroff Change Management in Government (2006) Harvard Business Publishing. URL: https://hbr.org/2006/05/change-management-in-government [accessed Jun 11 2021]. [in English].

5. Joris van der Voet, Ben Kuipers, Sandra Groeneveld (2015) Held back and pushed forward: leadingchange in a complex public sector environment. Journal of Organizational

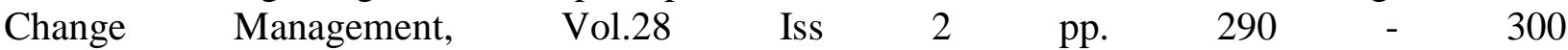
URL:https://www.researchgate.net/publication/276108170_Held_back_and_pushed_forward_Le ading_change_in_a_complex_public_sector_environment [accessed Jun 22 2021]. [in English]. 